\title{
Adipocyte hormone-sensitive lipase: a major regulator of lipid metabolism
}

\author{
BY DOMINIQUE LANGIN ${ }^{1}$, CECILIA HOLM ${ }^{2}$ AND \\ MAX LAFONTAN ${ }^{1}$ \\ ${ }^{1}$ Unité INSERM 317, Institut Louis Bugnard, Faculté de Médecine, Université Paul Sabatier, CHR \\ Rangueil, Bât. L3, 31054 Toulouse Cedex, France \\ ${ }^{2}$ Section for Molecular Signalling, Department of Cell and Molecular Biology, Lund University, \\ PO Box 94, 22100 Lund, Sweden
}

\section{Lipase hormono-sensible de l'adipocyte: un régulateur important du métabolisme lipidique}

\section{RÉSUMÉ}

Le tissu adipeux joue un rôle important dans le contrôle de la balance énergétique. La mobilisation des triacylglycérols par la lipase hormono-sensible (EC 3.1.1.3; LHS) est soumis à un contrôle direct par les hormones et neurotransmetteurs qui modulent les concentrations intracellulaires d'AMP cyclique (AMPc). L'hydrolyse des triacylglycérols par la LHS constitue l'étape limitante de la lipolyse. La LHS est phosphorylée sur le site régulateur (Ser552 dans la LHS humaine) par la protéine kinase dépendante de l'AMPc ( $E C$ 2.7.1.37) lorsque les concentrations intracellulaires d'AMPc augmentent. Cette phosphorylation conduit à l'activation de l'enzyme. Une deuxième site de phosphorylation (Ser554 dans la LHS humaine) dénommé site basal est la cible de la protéine kinase activée par l'AMP. La phosphorylation du site basal ne conduit pas à l'activation de la LHS et empèche la phosphorylation sur le site régulateur. La phosphorylation et l'activation de la protéine kinase activée par l'AMP constitue donc un mécanisme antilipolytique qui est fonctionnel sur cellules isolées mais dont l'importance physiologique n'est pas connue. Les ADN complémentaires de la LHS de plusieurs espèces ont été clonés et la structure des gènes de LHS de l'homme et de la souris sont connus. Différents domaines fonctionnels de la protéine ont été proposés. Une région d'homologie de séquences en amont de la sérine 424 du site catalytique avec cinq enzymes d'organismes procaryotes et une enzyme humaine a été décrite. La localisation chromosomique du gène de la LHS est connue chez l'homme (chromosome 19 , région $q 13 \cdot 1 \rightarrow 13 \cdot 2$ ), le porc et la souris. La mise en évidence de marqueurs polymorphiques dans le gène devrait permettre de tester l'hypothèse d'une implication de la LHS dans certaines maladies héréditaires du métabolisme lipidique. L'expression de la LHS varie selon la localisation anatomique du tissu adipeux chez le rat. Cette expression subit également des variations durant la gestation chez le rat et le cycle annuel chez les mammifères hibernants. Chez l'homme, les taux d'ARN messagers de la LHS sont diminués dans le tissu adipeux de certains patients atteints de cancer. L'activité enzymatique totale est diminuée chez les patients atteints d'hyperlipidémie familiale combinée mais pas chez les patients atteints du syndrome métabolique bien que, dans les deux cas, la lipolyse adipocytaire maximale soit diminuée. Les mécanismes moléculaires de contrôle de l'expression de la LHS sont pratiquement inconnus. 
All animals feed and fast intermittently. During evolution it has been necessary to develop precisely-regulated mechanisms to control the storage and release of metabolic fuels. In mammals, short-term fluctuations in energy balance are to some extent buffered by the glycogen stores. However, the capacity to store glycogen is limited. Longer-term imbalances between energy intake and expenditure are translated into changes in the body's store of lipid, mainly in the form of intracellular triacylglycerol (TAG) in adipose tissue. Thus, a highly developed adipose tissue is characteristic of all mammalian species. The vast majority of the body's TAG $(>95 \%)$ is found in adipose-tissue stores. Lipolysis refers to the hydrolysis of TAG, via di- and monoacylglycerol intermediates, to fatty acids and glycerol. Adipose-tissue lipolysis is the major regulator of the supply of lipid energy because it controls the release of fatty acids into the plasma. The rate-limiting step of adipose-tissue lipolysis is the hydrolysis of TAG by hormone-sensitive lipase ( $E C$ 3.1.1.3; HSL). Adipose tissue HSL is thus one of the enzymes determining whole-body lipid fuel availability. In the post-absorptive state, HSL activity accounts for most of the detectable lipolysis (Frayn et al. 1995).

The present review focuses mainly on recent advances in the understanding of HSL function and regulation in the adipocyte. Cellular aspects of lipid mobilization such as substrate selection have been recently reviewed (Lafontan \& Langin, 1995).

\section{MOLECULAR CONTROL OF HORMONE-SENSITIVE LIPASE ACTIVITY}

It is generally accepted that lipolysis is controlled mainly by sympathetic nervous system activity and plasma insulin levels. Basically, the lipolytic response of the fat cell depends on the balanced action of stimulatory and inhibitory pathways on HSL activity. The different steps of the lipolytic process leading to the activation of HSL are quite well defined (Fig. 1). The first cellular action of catecholamines and of a number of endocrine and/or paracrine regulators of lipolysis (e.g. adenosine and prostaglandins) is their binding to plasma membrane receptors. The stimulatory effect on lipolysis is strictly connected to the receptor-controlled increment of intracellular cAMP concentrations which in turn promotes activation of cAMP-dependent protein kinase (EC 2.7.1.37; cAMP-PK; Honnor et al. 1985) which phosphorylates HSL.

The first step leading to activation of the lipolytic cascade, involves the multi-regulated enzyme, adenylate cyclase ( $E C$ 4.6.1.1), which produces cAMP. Detailed mechanistic considerations have been reviewed recently by Lafontan \& Berlan (1993). Catecholamines are the most sophisticated regulators of fat cell function since they operate through five separate adrenergic receptors. They are able to stimulate three subtypes of $\beta$-adrenoceptors which are positively coupled to adenylate cyclase by Gs proteins, and an $\alpha_{2}$-adrenoceptor negatively coupled to the enzyme by a Gi protein. An important point in the metabolic actions initiated by endocrine and paracrine regulators concerns the functional significance of intracellular cAMP elevations promoted by receptor-mediated adenylate cyclase control. In fat cells, the lipolytic agents promote cAMP increments which largely overcome the concentrations required for maximal activation of cAMP-PK and lipolysis (Fain \& Garcia-Sainz, 1983; Honnor et al. 1985). Biphasic regulation of lipolysis by catecholamines has been demonstrated clearly in human fat cells (Berlan \& Lafontan, 1985; Mauriège et al. 1987). The interplay between $\alpha_{2}$ - and $\beta$-adrenoceptors plays a key role in the triggering of cAMP increments in fat cells; important speciesspecific differences exist. 


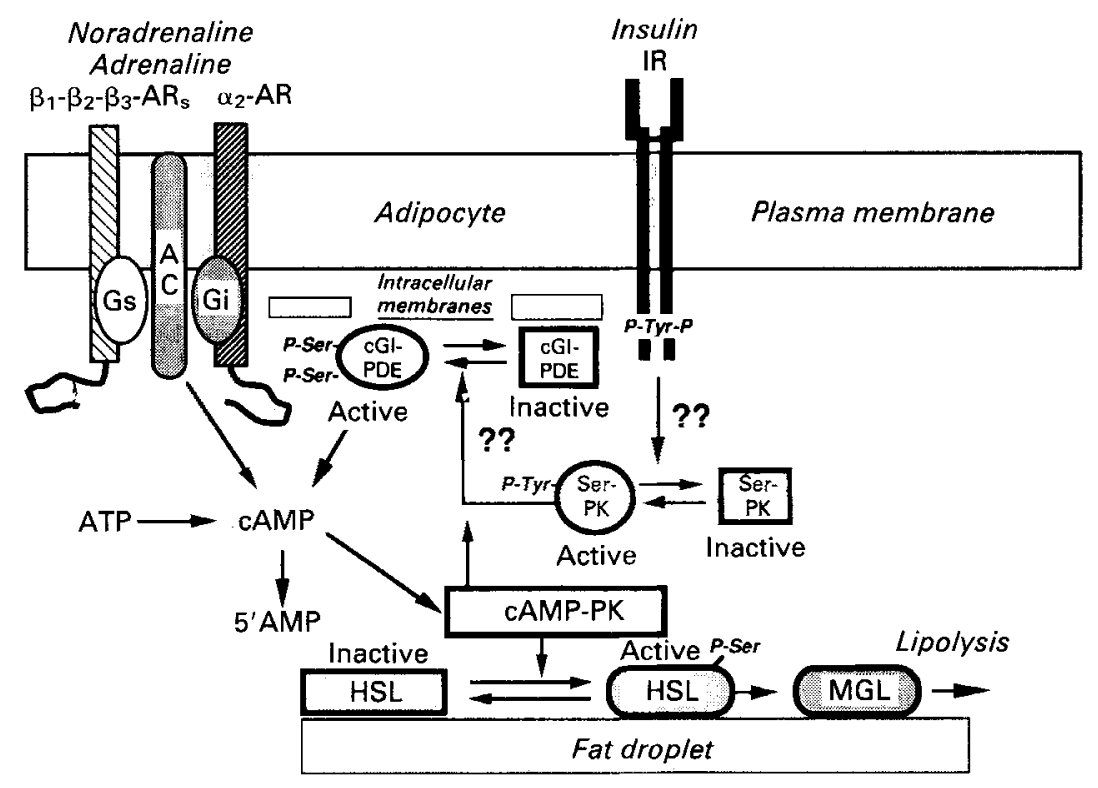

Fig. 1. Adipose-tissue lipolysis showing catecholamine receptors and insulin receptor (IR), G proteins (Gs and Gi), cGMP-inhibited low $K_{m}$ cAMP phosphodiesterase (EC 3.1.4.17; cGI-PDE) and the catalyst moieties of adenylate cyclase ( $E C$ 4.6.1.1; $A C)$. Three stimulatory $\beta$-adrenoceptors $\left(\beta_{1}, \beta_{2}\right.$ and $\left.\beta_{3}-A_{R_{s}}\right)$, coupled to $G$ s, and one inhibitory $\alpha_{2}$-adrenoceptor $\left(\alpha_{2}\right.$-AR), coupled to $\mathrm{Gi}$, exert antagonistic actions on AC activity, cAMP production, and cAMP-dependent protein kinase ( $E C$ 2.7.1.37; cAMP-PK) activity. Insulin promotes the degradation of cAMP via phosphorylation and activation of cGI-PDE which is associated with intracellular membranes. Phosphorylation of hormone-sensitive lipase (EC 3.1.1.3; HSL) by cAMP-PK is followed by HSL enzymic activation and lipolysis. Monoacylglycerol lipase (EC 3.1.1.23; MGL) hydrolyses the breakdown of monoacylglycerol into fatty acid and glycerol. Ser-PK, serine kinase.

Insulin is the physiologically important anti-lipolytic hormone. Initially insulin was thought to cause dephosphorylation of HSL and its deactivation by an effect which could involve phosphatase activation. However, its action is probably linked to a decrease in cellular cAMP levels. Insulin-induced reduction of cAMP could result from the inhibition of adenylate cyclase and/or from a stimulation of cGMP-inhibited low- $K_{m}$ cAMP-phosphodiesterase (EC 3.1.4.17; cGI-PDE). Effects through adenylate cyclase inhibition are still largely questionable and $\mathrm{Gi}$ proteins do not play a role in the transduction of the insulin signal in the adipocytes (Wesslau et al. 1993). Activation of cGI-PDE by insulin is believed to be the major mechanism whereby insulin reduces cellular cAMP levels. This activation is the result of serine phosphorylation of cGI-PDE (Degerman et al. 1990; Smith et al. 1991). A synergistic activation and phosphorylation of cGI-PDE was seen in response to insulin and catecholamines (Smith \& Manganiello, 1988; Smith et al. 1991). Results obtained in intact adipocytes are consistent with the notion that insulin mediates the phosphorylation of serine site(s) on cGI-PDE and promotes its activation (Eriksson et al. 1995). The insulin-induced activationphosphorylation of cGI-PDE is catalysed by a cGI-PDE serine kinase (Lopez-Aparicio et al. 1993). The identity of this protein is unknown. Very recently, it was shown that 


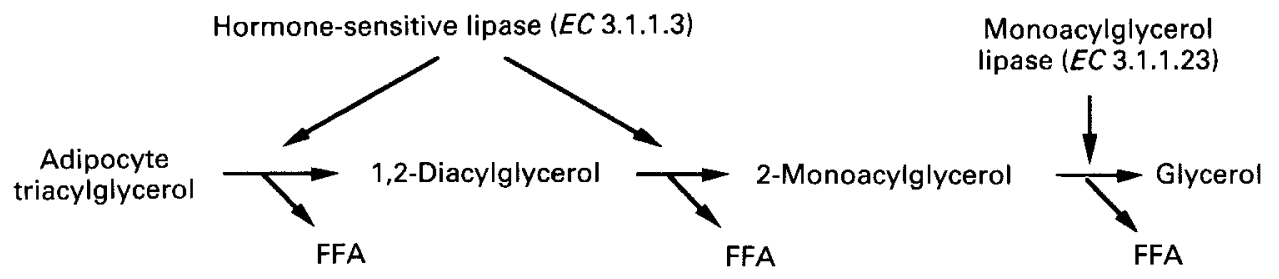

Fig. 2. Hydrolysis of triacylglycerols stored in adipocytes. The breakdown of triacylglycerols into diacylglycerols is the rate-limiting step in adipose tissue lipolysis. FFA, free fatty acids.

phosphatidyl inositol 3-kinase, an important mediator of insulin-dependent metabolic effects, was involved in mediating the anti-lipolytic effect of insulin at a step upstream from the activation of the cGI-PDE serine kinase. Further investigations should lead in the near future to a complete characterization of signal transduction steps involved in insulin-mediated anti-lipolysis.

In vivo, HSL catalyses the hydrolysis of TAG to diacylglycerol, and then to monoacylglycerol (Fig. 2). The hydrolysis of the monoacylglycerol-fatty acid bond is assured by monoacylglycerol lipase (EC 3.1.1.23). The abundance of this enzyme, which is not under hormonal control, is sufficient to avoid accumulation of intermediary products of lipolysis (Fredrikson et al. 1986). HSL exhibits positional specificity for the 1(3)-ester bond, although this specificity is less pronounced than that for lipoprotein lipase (EC 3.1.1.34; LPL) or pancreatic lipase $(E C$ 3.1.1.3). TAG are hydrolysed at a much lower rate than diacylglycerol. Therefore, the first step of lipolysis is rate-limiting. Moreover, phosphorylation of HSL by cAMP-PK is paralleled by an enhanced TAG lipase ( $E C$ 3.1.1.3) activity, whereas the activity against diacylglycerol is unchanged.

The hallmark of HSL, which distinguishes this enzyme from all other known lipases, is the control of its activity through phosphorylation (Fig. 3). A single serine residue (regulatory site) is phosphorylated by cAMP-PK, 1 mol phosphate being incorporated per mol subunit (Strålfors \& Belfrage, 1983). The reversible phosphorylation of the regulatory site controls the active state of the enzyme. However, the mechanism of activation is still unclear. HSL activity is increased 2-3-fold by cAMP-PK-mediated phosphorylation in vitro, while a more than 20 -fold increase in lipolytic rate is measured in intact fat cells in response to hormonal stimulation. The TAG emulsion used as substrate in vitro provides a much larger interfacial area than the larger TAG droplet present in the adipocyte (Strålfors et al. 1987). Hence, a high basal activity of HSL in the dephosphorylated form might be caused in vitro by favourable conditions for enzymesubstrate interaction, phosphorylation promoting a small increase in an already-high submaximal activity. The relationship between the subcellular distribution of HSL and its phosphorylation and activation may be important. HSL has some properties of an intrinsic membrane protein, for example it associates strongly with phospholipids, requires detergents for solubilization and exhibits an amphiphilic character (Holm et al. 1986). Redistribution of HSL may be a major event associated with phosphorylation and activation. On lipolytic stimulation, translocation of HSL from the cytosol to a particulate fraction was found in 3T3-L1 adipocytes (Hirsch \& Rosen, 1984). This view was recently strengthened. Using mild disruption of rat adipocytes and polyclonal antiserum directed against HSL, a translocation of phosphorylated HSL at the surface of 


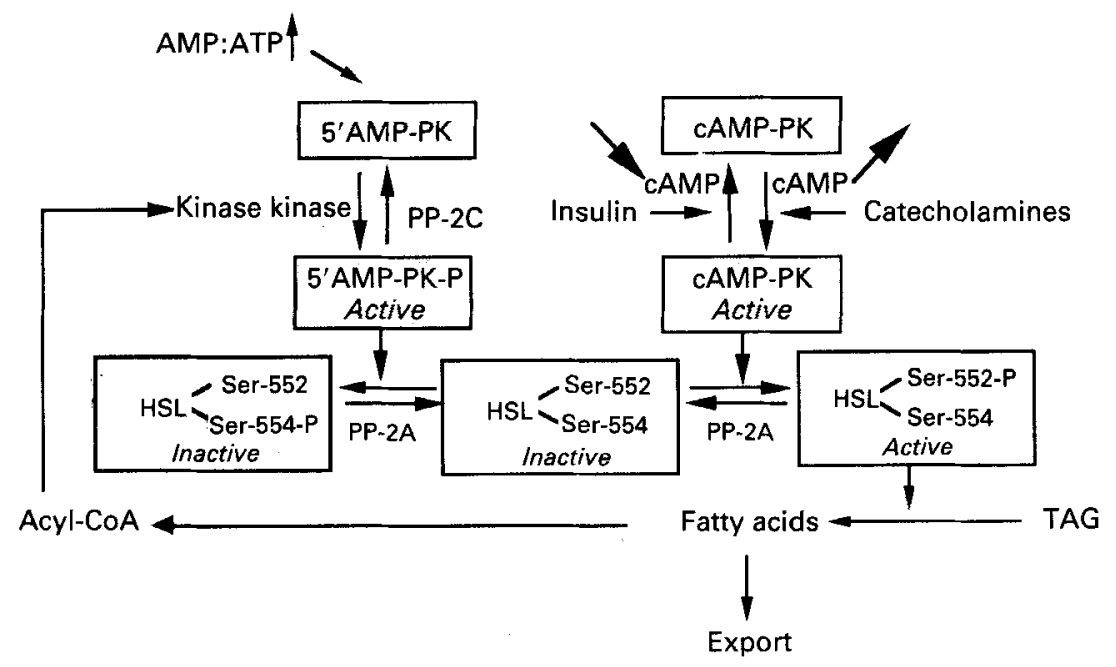

Fig. 3. Short-term regulation of hormone-sensitive lipase ( $E C$ 3.1.1.3; HSL). The diagram illustrates the phosphorylation of the regulatory site of human HSL (Ser552) by cAMP-dependent protein kinase (EC 2.7.1.37; cAMP-PK) and the hypothesis regarding the phosphorylation of the basal site (Ser554) by 5'. AMP-activated protein kinase (5'AMP-PK). PP-2A, PP-2C, protein phosphatases $2 \mathrm{~A}$ and $2 \mathrm{C}(E C 3.1 .3 .16)$; TAG, triacylglycerol.

the lipid droplet was demonstrated (Egan et al. 1992). The nature of the binding of the enzyme to the lipid droplet is not known. The primary structure of HSL does not show any highly hydrophobic regions, which could explain the propensity of HSL to bind to lipids. Early reports (Wise \& Jungas, 1978) have brought up the question as to whether a protein component located at the surface of the lipid droplet may undergo some kind of 'substrate activation' occurring concomitantly with HSL activation and governing droplet-driven translocation of HSL. It could be speculated that perilipins, specific adipocyte lipid-droplet-associated proteins, are possible candidates as 'docking' proteins for HSL (Greenberg et al. 1991). These proteins, probably contribute to the organization of lipid droplets and lipid vacuoles found in mature adipocytes (Hare et al. 1994). Perilipins are phosphorylated by cAMP-PK in parallel with activation of lipolysis. This event could represent the 'substrate activation' process. The recent isolation of cDNA for perilipins will allow detailed analysis of their role in fat cells (Greenberg et al. 1993).

In addition to the regulatory site, another serine residue (basal site) can be phosphorylated (Fig. 3). Three protein kinases i.e. $\mathrm{Ca}^{2+} /$ calmodulin-dependent protein kinase II (EC 2.7.1.123), glycogen synthase kinase-4 (EC 2.7.1.37) and the 5'-AMPactivated protein kinase have been shown to phosphorylate site 2 in vitro. Phosphorylation of site 2 does not directly alter HSL activity, but can exert a regulatory role since phosphorylation of site 1 and site 2 on HSL are mutually exclusive. Using a synthetic peptide, based on the sequence surrounding sites 1 and 2 of HSL, it was shown that phosphorylation of the peptide at site 2 totally prevents the subsequent phosphorylation of site 1 and vice versa (Garton et al. 1989; Garton \& Yeaman, 1990). Evidence for a role of $5^{\prime}$-AMP-activated kinase in adipocytes was provided by use of a cell-permeable precursor of 5-amino-imidazole 4-carboxamide ribonucleoside monophosphate (ZMP) 
which mimicks the effect of AMP on allosteric activation of rat liver 5'-AMP-activated kinase. Incubation of isolated adipocytes with the ZMP precursor reduces isoprenalineinduced lipolysis (Sullivan et al. 1994; Corton et al. 1995). It is not clear at present in which physiological situations the 5'-AMP-activated protein kinase regulates HSL activity. AMP not only allosterically activates the enzyme, but also promotes its phosphorylation and activation by a kinase kinase. Conditions which induce cellular stress cause a large increase in intracellular AMP as well as a depletion of ATP and these changes correlate with activation of the 5'-AMP-activated protein kinase. The physiological targets of this enzyme are, besides HSL, acetyl-CoA carboxylase (EC 6.4.1.2) and 3-hydroxy-3-methylglutaryl-CoA reductase $(E C$ 1.1.1.34) which catalyse regulated steps in the biosynthesis of fatty acids and isoprenoids and/or steroids respectively. Therefore, in conditions of cellular stress, $5^{\prime}$-AMP-activated protein kinase has a possible protective role through inactivation of key enzymes involved in the synthesis or release of fatty acids and cholesterol (Hardie \& McIntosh, 1992). Another possible regulation of HSL by $5^{\prime}$-AMP-activated protein kinase involves fatty acids. The kinase kinase is activated by sub-micromolar concentrations of palmitoyl-CoA. When adipocyte fatty acids released by lipolysis and converted to CoA esters reach a level which triggers activation of the kinase kinase and 5'-AMP-activated protein kinase, phosphorylation of site 2 of HSL could occur, and prevent the cAMP-PK-dependent activation of the enzyme and further release of fatty acids. This kinase cascade could constitute a novel form of feedback regulation of lipolysis. Direct negative feedback of HSL by oleoyl-CoA and oleic acid, in a non-competitive manner, has been demonstrated in in vitro assays (Jepson \& Yeaman, 1992). Inhibition operates via binding of fatty acids to a specific site on the enzyme protein. This coordinated feedback mechanism whereby elevated levels of fatty acids or fatty acyl-CoA regulate the level of free fatty acids in the cell, via inhibition of their mobilization from fat stores, is attractive, although its demonstration in vivo has not yet been proved. The existence of additional processes involved in the control of non-esterified fatty acid disposal (for example, attachment to fatty acidbinding proteins, controlled outflow from fat cell by fatty acid transporter, limited access in cell compartments) complicates the delineation of the limiting steps.

HSL is a good substrate for phosphatases $2 \mathrm{~A}$ and 2C (EC 3.1.3.16; Olsson \& Belfrage, 1988). Phosphatases 1 and $2 \mathrm{~A}$ appear to contribute the major phosphatase activities within rat adipocytes, whereas phosphatase $2 \mathrm{C}$ is present at low levels (Wood et al. 1993). Phosphatases $2 \mathrm{~A}$ and $\mathrm{C}$ exhibit similar degrees of activity towards the regulatory site, but the basal site is dephosphorylated predominantly by phosphatase $2 \mathrm{~A}$. It is considered that the control of HSL phosphorylation-dephosphorylation by insulin and catecholamines occurs predominantly at the level of cAMP concentration rather than at the level of phosphatase activity (Manganiello et al. 1992).

\section{GENOMIC ORGANIZATION AND FUNCTIONAL DOMAINS OF HORMONE-SENSITIVE LIPASE}

CDNA for HSL have been obtained from both rat and human adipose tissues (Holm et al. 1988; Langin et al. 1993). The human HSL gene is composed of nine coding exons spanning eleven kilobases and encodes a protein that is 775 amino acids long (Fig. 4; Langin et al. 1993) (J. A. Contreras, T. Østerlund, D. Langin and C. Holm, unpublished results). The organization of the mouse HSL gene is strikingly similar to its human 
counterpart ( $\mathrm{Li}$ et al. 1994). Each putative functional region of HSL is encoded by a different exon, suggesting that HSL could be a mosaic protein. Exon 6 encodes a motif for the serine of the catalytic site $\left(\mathrm{Ser}^{424}\right)$ found in most lipases. Site-directed mutagenesis of the serine residue leads to a complete abolition of both lipase and esterase activity (Holm et al. 1994). It has been shown for several lipases that the catalytic site serine is part of a catalytic triad that includes also a histidine and an aspartic acid (Derewenda, 1994). The catalytic triad is responsible for nucleophilic attack on the carbonyl-C of the scissile ester bond, which is the first step of the hydrolysis of ester bonds. X-ray structure and site-directed mutagenesis will be necessary to identify these residues, since HSL does not show homology with other eukaryotic lipases (see below). The phosphorylation site sequence (Met-Arg-Arg-Ser ${ }^{552}$-Val-Ser ${ }^{554}$-Glu-Ala-Ala) is encoded by exon 8 . Exon 9 encodes a potential lipid-binding domain that shows homology with sequences present in other lipid-binding proteins, including lecithin: cholesterol acyltransferase (EC 2.3.1.43), cholesteryl ester transfer protein and pancreatic carboxyl ester lipase (EC 3.1.1.1; Au-Young \& Fielding, 1992). Overall, the HSL protein is highly conserved between species. Human HSL is $82 \%$ identical to both mouse and rat HSL. However, a stretch of amino acids upstream of the phosphorylation site region diverges significantly. Compared with the rat sequence, there is a deletion of six amino acids in mouse HSL and of twelve amino acids in human HSL. The functional importance of this deletion, if any, is presently under investigation.

HSL shares no homology, except for a pentapeptide motif arouind the catalytic site serine (Gly-Xaa-Ser-Xaa-Gly), with other eukaryotic lipases. In particular, HSL does not belong to the so-called lipase gene family that includes LPL, hepatic lipase ( $E C$ 3.1.1.3) and pancreatic lipase. However, it does show sequence similarity to five prokaryotic enzymes from distantly related eubacteria (Langin \& Holm, 1993). The region of highest similarity is bordered by the pentapeptide motif (Gly-Asp-Ser-Ala-Gly) which is identical in the six proteins and a His-Gly dipeptide which may constitute one of the hydrophobic 'wings' flanking the catalytic site (Fig. 4). The strongest sequence similarity is found with lipase 2 (EC 3.1.1.3) of Moraxella TA144, an antarctic bacterium. Since lipase 2 catalyses lipolysis below $4^{\circ}$, the cold adaptability of HSL, an unexpected property for a mammalian lipase, was investigated. HSL retained distinctly more catalytic activity at low temperatures than either LPL or carboxyl ester lipase. The so-called 'cold adaptability' of HSL has recently been discussed (Langin \& Holm, 1993; Langin et al. 1993). This unexpected property of HSL could be of critical survival value when lipids mobilized at low temperature are the primary energy sources, e.g. in hibernating mammals and poikilotherms. To date, HSL shows sequence similarity with only one eukaryotic protein, a human liver arylacetamide deacetylase (EC 3.1.1.1) (Probst et al. 1994). This esterase is involved in the metabolic activation of arylamine carcinogens. Interestingly, the first region of homology is bordered by the pentapeptide motif and the His-Gly dipeptide. A second region of homology was found in the C-terminal part of the protein downstream of the phosphorylation site domain. This region is also found in Moraxella TA144 lipase 2 and other prokaryotic enzymes with a lower similarity (Hemilä et al. 1994). Therefore, it seems that during the course of evolution regions important for the lipase and/or esterase activity have been conserved whereas the insertion of the regulatory domain of HSL, i.e. the phosphorylation site region, is probably a more recent event. 
(a)

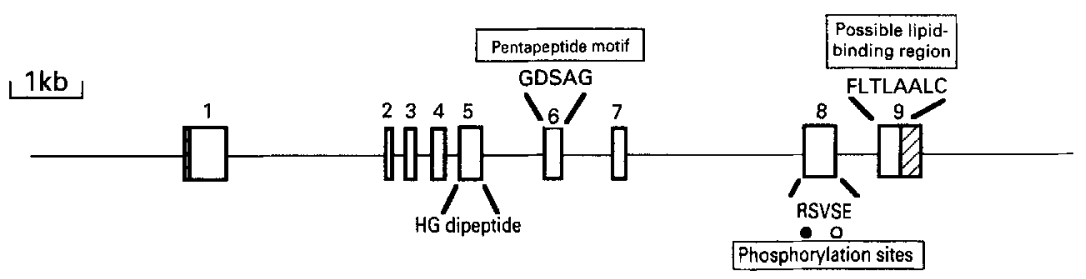

(b)

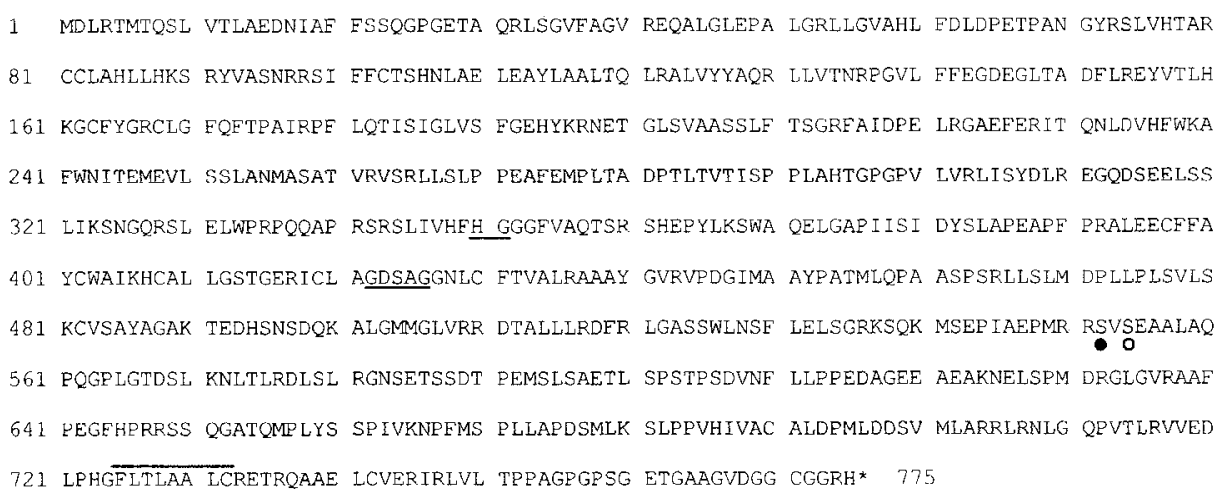

Fig. 4. Genomic organization and amino acid sequence of human hormone-sensitive lipase (EC 3.1.1.3). (a) The exon-intron organization of the human hormone-sensitive lipase gene. ( $\square$ ), Exons; ( - ), introns; ( $\bullet$ ), non-coding regions. Different functional regions are encoded by different exons as indicated. (b) The amino acid sequence, indicating the histidine-glycine dipeptide (shown in exon 5) and the catalytic site serine (shown in exon 6), the regulatory phosphorylation site (Ser552) (O) and the basal phosphorylation site (Ser554) (O) and a putative lipid-binding domain (indicated in exon 9).

\section{HORMONE-SENSITIVE LIPASE AND FAMILIAL DISORDERS OF LIPID METABOLISM}

HSL is a candidate gene for obesity and related disorders because of its strategic role in the control of lipid metabolism. A precise knowledge of the chromosomal localization of the HSL gene in man and animal models is important for the study of the genetics of adipose tissue metabolism and related disorders. The human HSL locus, designated LIPE, is located on the long arm of chromosome 19 (q13.1 $\rightarrow 13 \cdot 2$ region; Holm et al. 1988; Schonk et al. 1990). Several familial disorders, e.g. myotonic dystrophy and malignant hyperthermia, have been mapped to this region of chromosome 19. A refined map of the region ruled out the localization of the HSL gene at the myotonic dystrophy locus (Schonk et al. 1990). With respect to malignant hyperthermia, the gene is located at the proper locus very close to the gene for the ryanodine receptor ( $\mathrm{a} \mathrm{Ca}^{2+}$-release channel of the skeletal muscle sarcoplasmic reticulum; Levitt et al. 1995). Since free fatty acid release is increased in muscle homogenates from affected patients, HSL has been proposed as a candidate gene (Levitt et al. 1990). Some breeds of swine constitute a good model for the study of malignant hyperthermia and it was shown that a mutation in the ryanodine receptor gene was associated with the disease (Fujii et al. 1991). As in man, the HSL gene in pig is located very close to the ryanodine receptor gene on chromosome 
6q12 (Gu et al. 1992; Chowdhary et al. 1994). Therefore, it is still of interest to test the hypothesis that variability in the HSL gene could be linked to, or contribute to, some symptoms of malignant hyperthermia in man and in the pig (Levitt et al. 1995).

DNA polymorphisms are of great interest to relate variance in the phenotype and genetic variation. A polymorphic marker, D19S120, was identified within a human genomic clone selected by hybridization to a rat HSL cDNA and a poly(dG-dT) oligonucleotide probe (Levitt et al. 1992). D19S120 was subsequently localized to the short arm of chromosome 19 (p13.3 region) by linkage (Jedlicka et al. 1994). These findings raised the possibility of the existence of a HSL pseudogene or that the human HSL gene was duplicated on the short arm of chromosome 19. Using cosmid clones from the $q 13 \cdot 1 \rightarrow 13.2$ and $p 13 \cdot 3$ regions no evidence was found of sequences related to HSL cDNA in the 19 p 13.3 region. D19S120 was probably identified in a human genomic clone obtained from an artifactual signal due to a reduced stringency used with the rat HSL cDNA probe (Laurell et al. 1995). Recently, a high polymorphic dinucleotide repeat was found upstream of exon 8 in the HSL gene. Unlike D19S120, this marker provides a tool for analysing the importance of LIPE in disorders of lipid metabolism (Levitt et al. 1995).

The mouse is a valuable animal model to examine the potential role of candidate genes in complex traits, such as non-insulin-dependent diabetes mellitus and obesity, in which multiple genes are involved. LIPE is near the gene cluster containing apolipoproteins CII and $\mathrm{E}$ genes on a region of chromosome 7 homologous to human chromosome $19 \mathrm{q}$ (Warden et al. 1993). Two mouse monogenic obesity loci, Ad (adult obesity and diabetes) and Tub (tubby) map to chromosome 7, but LIPE is clearly distinct from these loci (Warden et al. 1993; Wang et al. 1994). A multifactorial mouse model has recently been investigated (Warden et al. 1995). Four obesity loci were identified. A chromosome 7 locus was shown to affect body fat, total cholesterol and hepatic lipase activity. However, as in the Tub model, LIPE is distinct from this locus. Although it is plausible that HSL may be implicated in some forms of obesity, no obesity-related trait has so far been associated with LIPE.

\section{REGULATION OF HORMONE-SENSITIVE LIPASE EXPRESSION}

Acute regulation of HSL by catecholamines and insulin is well documented (Strålfors et al. 1987; Frayn et al. 1995), but few studies have been devoted to variations in HSL gene expression. Being the rate-limiting enzyme in adipose tissue lipolysis, any variation in the amount of HSL protein would have an impact on the capacity of adipose tissue to mobilize TAG. The recent cloning of HSL cDNA in several species has provided tools that permit accurate mRNA determination and, using recombinant HSL produced in insect cells or HSL-bacterial fusion proteins, large amounts of antibodies against HSL can now be produced (Kraemer et al. 1993; Holm et al. 1994). The acute regulation of HSL through reversible phosphorylation is studied by measuring glycerol and/or fatty acids released from the adipocyte since there is no satisfactory method to probe directly the proportion of HSL in active form, i.e. HSL phosphorylated at the regulatory site. Measurement of HSL activity using a diacylglycerol analogue as substrate is an indirect measure of total HSL protein. The adaptation of existing methods allows the measurement of total enzyme activity and of HSL mRNA levels in samples of human adipose tissue obtained from small biopsies (Frayn et al. 1993).

The lipolytic activity of fat cells has been shown to vary according to the anatomic 
location of the fat depot. The understanding of the molecular mechanisms underlying regional variations of lipolysis is important with respect to the consequences of the metabolic disturbances associated with obesity. In particular, accumulation of visceral fat is associated with a higher risk of cardiovascular disease (Björntorp, 1990). In the rat, subcutaneous adipocytes show lower maximal lipolysis rates than adipocytes from internal fat stores (Tavernier et al. 1995). The impaired capacity of mobilization of subcutaneous adipose tissue is explained by a lower expression of HSL, i.e. lower activity, protein and mRNA levels. The expression of the three $\beta$-adrenoceptors is also impaired in subcutaneous fat depots (Sztalryd \& Kraemer, 1994; Tavernier et al. 1995). Ageing is accompanied by a decrease in adipose tissue lipolysis in man and in the rat (Lönnqvist et al. 1990; Gettys et al. 1995), for which a post-receptor defect in the lipolytic cascade has been suggested as an explanation (Lönnqvist et al. 1990). However, HSL mRNA levels (Kraemer et al. 1991) and activity (D. Langin, unpublished results) did not appear to vary in rat epididymal adipose tissue between 3 weeks and 2 years of age.

Fasting induces an increase in plasma concentrations of free fatty acids in rats and in human subjects. This effect is due to the combination of an acceleration of the rate of lipolysis and a diminished rate of re-esterification (Frayn et al. 1995). The acute increase in free fatty acid concentrations is most probably due to an increase in HSL phosphorylation and activation via increased cAMP levels since the plasma concentration of insulin, the main anti-lipolytic hormone promoting cAMP degradation, is decreased. In the rat, regulation of HSL expression occurs after $3 \mathrm{~d}$ of starvation. This effect is pre-translational since activity, protein and mRNA levels are increased (Sztalryd \& Kraemer, 1994).

In many physiological situations, a coordinated regulation of HSL and LPL is observed in white adipose tissue. HSL is concerned with fat mobilization whereas LPL is responsible for the hydrolysis of TAG contained in lipoprotein particles, thereby governing the input of free fatty acids to be stored as TAG. Pregnancy is a physiological state characterized by changes in maternal adipose tissue mass. Fat accumulates during the early stages of pregnancy and decreases during the later phases. In rat lumbar adipose tissue, LPL activity decreases to one-third that of virgin control animals with less than $10 \%$ initial LPL mRNA levels. HSL activity increased maximally $1 \cdot 5$-fold with a fourfold increase in HSL mRNA levels. The HSL:LPL mRNA and activity values are greatly enhanced during late pregnancy. This enhancement coincides with increments in plasma free fatty acid and glycerol levels indicating increased adipose tissue mobilization. These results suggest that changes in gene expression are important for the institution of a catabolic state in late pregnancy (Martin-Hidalgo et al. 1994). Another reciprocal regulation of HSL and LPL is shown by hibernating mammals. In the summer and early autumn, hibernators such as the yellow-bellied marmot (Marmota flaviventris) dramatically increase food intake and double their spring body mass. Throughout the winter and early spring, marmots fast and body mass declines due to intense adipose tissue mobilization. During the hibernating period there is an increase in plasma free fatty acids suggesting sustained lipolysis. LPL mRNA levels are high during the mass gain phase, whereas HSL mRNA levels are high during the fasting period (Wilson et al. 1992). As in pregnancy, these results suggest that the LPL and HSL genes are coordinately regulated to control fat depot mass.

Studies of HSL regulation in human subjects are beginning to emerge. A weightreduction programme in women with upper-body obesity leads after 5 weeks of 
stabilization at the new BMI to an increased efficiency of lipolysis. The in vitro sensitivity of $\beta_{2}$-adrenoceptors is increased whereas resting lipolytic rate is decreased. This latter effect is most probably due to a $50 \%$ reduction in HSL activity. Changes in circulating levels of catecholamines, insulin and testosterone may play a role in these modifications of adipocyte function (Reynisdottir et al. 1995b). Altered lipid metabolism in cancer patients is associated with hyperlipidaemia, depletion of fat stores and progressive weight loss. This phenomenon can occur without a decrease in food intake, suggesting that increased lipolysis may be involved. A twofold increase in HSL mRNA levels correlated with increased plasma free fatty acid levels was found in adipose tissue of cancer patients (Thompson et al. 1993). This interesting observation needs further support by studying, in parallel with HSL mRNA and activity levels, fat-cell lipolysis in a larger number of cancer patients with controlled energy and protein intake. Some disorders of lipid metabolism such as the insulin-resistance syndrome and familial combined hyperlipidaemia are associated with impaired fat-cell lipolysis (Reynisdottir et al. 1994, 1995a). Familial combined hyperlipidaemia is the most common familial form of hyperlipidaemia in young survivors of myocardial infarction. The insulin-resistance syndrome has been defined as an association of insulin resistance, elevated triacylglycerolaemia and decreased HDL-cholesterol (Reaven, 1988). These metabolic disturbances are very often found in patients with upper-body obesity, which is also associated with an increased risk of developing non-insulin-dependent diabetes mellitus and coronary heart disease (Frayn \& Coppack, 1993). In insulin-resistance syndrome and familial combined hyperlipidaemia, a decrease of maximally-stimulated lipolysis was shown and this defect occurred at a post-receptor level. HSL activity was decreased in patients with familial combined hyperlipidaemia but not in patients with insulinresistance syndrome (Reynisdottir et al. 1995a; S. Reynisdottir and D. Langin, unpublished results). These results indicate that multiple mechanisms can account for diminished maximal lipolysis at the level of cAMP-dependent protein kinase-HSL complex. A decrease in HSL protein level explains impaired lipolysis in familial combined hyperlipidaemia whereas a post-translational defect, for example in the mechanism of translocation and/or activation of HSL, could be of importance in the insulin-resistance syndrome.

Few data are available on the factors controlling HSL gene expression. Neutral-TAG lipase activity is greatly enhanced during adipocyte differentiation of 3T3-L1 fibroblasts (Kawamura et al. 1981). A marked increase in HSL activity and mRNA levels is also observed during differentiation of human pre-adipocytes (D. Langin, M. Dauzats and M. Lafontan, unpublished results). HSL is generally classified as a late marker of differentiation, along with the fatty acid-binding protein and glucose transporter 4 (Ailhaud et al. 1992). Overexpression of HSL in murine 3T3-F442A fibroblasts prevents the accumulation of TAG in pre-adipocytes induced to differentiate. This is accompanied by a slight decrease or no change in LPL expression, an early marker of differentiation, and a marked drop in the expression of late markers of differentiation such as the fatty acid-binding protein and glycerol-3-phosphate dehydrogenase ( $E C$ 1.1.99.5). Therefore, aberrant expression of HSL before differentiation impairs the appearance of late markers and of a normal adipocyte phenotype (Sztalryd et al. 1995). Whether a disruption of cellular lipid pathways is involved remains to be investigated. Although the acute control of HSL activation in response to hormones is well known (Fig. 1), very few data are available concerning the modulation of HSL expression by 
hormones and cytokines. An increase in HSL mRNA levels in isolated rat adipocytes in response to sub-micromolar concentrations of the glucocorticoid dexamethasone has been reported after $24 \mathrm{~h}$ exposure (Slavin et al. 1994). Much interest has been devoted recently to the role of tumour necrosis factor $\alpha$ (TNF $\alpha$ ) in obesity. TNF $\alpha$ seems to be involved in the insulin-resistant state of obesity (Spiegelman \& Hotamisligil, 1993). $\mathrm{TNF} \alpha$ expression in adipose tissue is increased in obese patients. Body-weight reduction in these patients results in a decrease in TNF $\alpha$ mRNA expression associated to an improvement in insulin sensitivity (Hotamisligil et al. 1995; Kern et al. 1995). TNFo causes an increase in adipose tissue lipolysis (Patton et al. 1986; Kawakami et al. 1987). Surprisingly, HSL total activity and mRNA levels are decreased after TNF $\alpha$ treatment of 3T3-L1 adipocytes (Sumida et al. 1990). These apparently contradictory observations might be explained by the de-differentiating effect of TNFo, which leads in cultured cells to a decrease in expression of several markers including C/EBP $\alpha$, a transcription factor crucial for the acquisition of the adipocyte phenotype (Ron et al. 1992), and by a strong direct lipolytic effect via an unknown pathway.

\section{CONCLUSION AND FUTURE TRENDS}

In the present review, we have focused on the role of HSL in the hydrolysis of adipose tissue TAG. The enzyme is expressed in other tissues, most notably steroidogenic tissues such as testes, adrenals and ovaries (Holm et al. 1987). The role of HSL in these tissues is not known. HSL could hydrolyse TAG or cholesteryl esters since both classes of molecules are HSL substrates. A possible importance of the cholesteryl esterase activity of HSL in adipose tissue also remains to be investigated.

The accumulation of data derived from molecular biology will facilitate research on different aspects of HSL. The cloning of human, mouse and rat cDNA was a prerequisite for the design of expression vectors. Large amounts of recombinant HSL can now be produced using a baculovirus-insect cell expression system (Holm et al. 1994). The functional domains of the protein are being mapped using proteolytic cleavage in combination with site-directed mutagenesis. The availability of the protein in large quantities is also critical for the determination of the three-dimensional structure of HSL. Much has recently been learnt from crystallographic studies of lipase-mediated catalysis (Derewenda, 1994). Of particular importance will be the studies of the relationship between the phosphorylation sites and the catalytic site, since HSL is the only known eukaryotic lipase which is regulated directly through phosphorylation. Establishment of transgenic mouse lines expressing HSL mutants will be very important for studies of structure-function relationships in vivo.

The precise chromosomal localization of the HSL locus in several species and the characterization of DNA polymorphisms will facilitate genetic studies and permit the testing of the hypothesis of the involvement of HSL in inherited diseases of lipid metabolism.

New insights into the regulation of HSL expression are also expected. Clinical data are starting to accumulate showing that in certain disorders and physiological states HSL expression varies. The possibility of measuring HSL total activity and mRNA levels in small adipose-tissue biopsies is important in understanding the level of regulation (preor post-translational). The combination of lipolysis experiments and HSL studies in man and animal models will lead to new findings in the near future. The study of the 
molecular mechanisms underlying the regulation of HSL expression should be facilitated by the use of mouse pre-adipocyte cell lines and human pre-adipocyte primary cultures. The elucidation of HSL genomic organization with the characterization of flanking regions is important for studies of regulatory elements controlling HSL gene transcription. Transgenic mice expressing promoter-reporter gene constructions will be a necessary complement to studies on pre-adipocyte cell lines and in vitro characterization of transcription factors.

The authors are members of the BIOMED I Concerted Action EUROLIP supported by the European Union. They thank Dr Keith N. Frayn (Oxford Lipid Metabolism Group, University of Oxford) for helpful discussion and critical reading of the manuscript.

\section{REFERENCES}

Ailhaud, G., Grimaldi, P. \& Négrel, R. (1992). Cellular and molecular aspects of adipose tissue development. Annual Review of Nutrition 12, 207-233.

Au-Young, J. \& Fielding, C. J. (1992). Synthesis and secretion of wild-type and mutant human plasma cholesteryl ester transfer protein in baculovirus-transfected insect cells: the carboxyl-terminal region is required for both lipoprotein binding and catalysis of transfer. Proceedings of the National Academy of Sciences, USA 89, 4094-4098.

Berlan, M. \& Lafontan, M. (1985). Evidence that epinephrine acts preferentially as an antilipolytic agent in abdominal human subcutaneous fat cells: assessment by analysis of beta- and alpha-2-adrenoceptors properties. European Journal of Clinical Investigation 15, 341-346.

Björntorp, P. (1990). 'Portal' adipose tissue as a generator of risk factors for cardiovascular disease and diabetes. Arteriosclerosis 10, 493-496.

Chowdhary, B. P., Thomsen, P. D., Harbitz, I., Landset, M. \& Gustavsson, I. (1994). Precise localization of the genes for glucose phosphate isomerase (GPI), calcium release channel (CRC), hormone-sensitive lipase (LIPE), and growth hormone (GH) in pigs, using nonradioactive in situ hybridization. Cytogenetics and Cell Genetics 67, 211-214.

Corton, J., Gillespie, J., Hawley, S. \& Hardie, D. (1995). 5-Aminoimidazole-4-carboxamide ribonucleoside. A specific method for activating AMP-activated protein kinase in intact cells? European Journal of Biochemistry 229, 558-565.

Degerman, E., Smith, C. J., Tornquist, H., Vasta, V., Belfrage, P. \& Manganiello, V. C. (1990). Evidence that insulin and isoprenaline activate the cGMP-inhibited low Km cAMP-phosphodiesterase in rat fat cells by phosphorylation. Proceedings of the National Academy of Sciences, USA 87, 533-537.

Derewenda, Z. S. (1994). Structure and function of lipases. Advances in Protein Chemistry 45, 1-52.

Egan, J. J., Greenberg, A. S., Chang, M.-K., Wek, S. A., Moos, M. C. Jr \& Londos, C. (1992). Mechanism of hormone-stimulated lipolysis in adipocytes: Translocation of hormone-sensitive lipase to the lipid storage droplet. Proceedings of the National Academy of Sciences, USA 89, 8537-8541.

Eriksson, H., Ridderstråle, M., Degerman, E., Ekholm, D., Smith, C. J., Manganiello, V. C., Belfrage, P. \& Tornquist, H. (1995). Evidence for the key role of the adipocyte cGMP-inhibited cAMP phosphodiesterase in the antilipolytic action of insulin. Biochimica et Biophysica Acta 1266, 101-107.

Fain, J. N. \& Garcia-Sainz, J. A. (1983). Adrenergic regulation of adipocyte metabolism. Journal of Lipid Research 24, 945-966.

Frayn, K. \& Coppack, S. (1993). Insulin resistance, adipose tissue and coronary heart disease. Clinical Science 82, 1-8.

Frayn, K. N., Coppack, S. W., Fielding, B. A. \& Humphreys, S. M. (1995). Coordinated regulation of hormone-sensitive lipase and lipoprotein lipase in human adipose tissue in vivo: implications for the control of fat storage and fat mobilization. Advances in Enzyme Regulation 35, 163-178.

Frayn, K. N., Langin, D., Holm, C. \& Belfrage, P. (1993). Hormone-sensitive lipase: quantitation of enzyme activity and mRNA level in small biopsies of human adipose tissue. Clinica Chimica Acta 216, 183-189.

Fredrikson, G., Tornqvist, H. \& Belfrage, P. (1986). Hormone-sensitive lipase and monoacylglycerol lipase are both required for complete degradation of adipocyte triacylglycerol. Biochimica et Biophysica Acta 876, 288-293. 
Fujii, J., Otsu, K., Zorzato, F., De Leon, S., Khanna, V. K., Weiler, J. E., O'Brien, P. J. \& MacLennan, D. H. (1991). Identification of a mutation in porcine ryanodine receptor associated with malignant hyperthermia. Science 253, 448-451.

Garton, A. J., Campbell, D. G., Carling, D., Hardie, D. G., Colbran, R. J. \& Yeaman, S. J. (1989). Phosphorylation of bovine hormone-sensitive lipase by the AMP-activated protein kinase. A possible antilipolytic mechanism. European Journal of Biochemistry 179, 249-254.

Garton, A. J. \& Yeaman, S. J. (1990). Identification and role of the basal phosphorylation site on hormone-sensitive lipase. European Journal of Biochemistry 191, 245-250.

Gettys, T. W., Rohlfs, E. M., Prpic, V., Daniel, K. W., Taylor, I. L. \& Collins, S. (1995). Age-dependent changes in $\beta$-adrenergic receptor subtypes and adenylyl cyclase activation in adipocytes from Fischer 344 rats. Endocrinology 136, 2022-2032.

Greenberg, A., Egan, J. J., Wek, S. A., Garty, N. B., Blanchette-Mackie, E. J. \& Londos, C. (1991). Perilipin, a major hormonally regulated adipocyte-specific phosphoprotein associated with the periphery of lipid storage droplets. Journal of Biological Chemistry 266, 11341-11346.

Greenberg, A. S., Egan, J. J., Wek, S. A., Moos, M. C. Jr, Londos, C. \& Kimmel, A. R. (1993). Isolation of cDNAs for perilipins $\mathrm{A}$ and $\mathrm{B}$ : sequence and expression of lipid droplet-associated proteins of adipocytes. Proceedings of the National Academy of Sciences, USA 90, 12035-12039.

Gu, F., Harbitz, I., Chowdhary, B. P., Bosnes, M. \& Gustavsson, 1. (1992). Chromosomal localization of the hormone sensitive lipase (LIPE) and insulin receptor (INSR) genes in pigs. Hereditas 117, 231-236.

Hardie, D. \& McIntosh, R. (1992). AMP-activated protein kinase: an archetypal protein kinase cascade. BioEssays 14, 699-704.

Hare, J. F., Taylor, K. \& Holocher, A. (1994). Energy-dependent protein-triacylglycerol interaction in a cell-free system from 3T3-L1 adipocytes. Journal of Biological Chemistry 269, 771-776.

Hemilä, H., Koivula, T. T. \& Palva, I. (1994). Hormone-sensitive lipase is closely related to several bacterial proteins, and distantly related to acetylcholinesterase and protein lipase: identification of a superfamily of esterases and lipases. Biochimica et Biophysica Acta 1210, 249-253.

Hirsch, A. H. \& Rosen, O. M. (1984). Lipolytic stimulation modulates the subcellular distribution of hormone-sensitive lipase in 3T3-L1 cells. Journal of Lipid Research 25, 665-677.

Holm, C., Belfrage, P. \& Fredrikson, G. (1987). Immunological evidence for the presence of hormonesensitive lipase in rat tissues other than adipose tissue. Binchemical and Biophysical Research Communications 148, 99-105.

Holm, C., Belfrage, P., Østerlund, T., Davis, R. C., Schotz, M. C. \& Langin, D. (1994). Hormone-sensitive lipase: structure, function, evolution and overproduction in insect cells using the baculovirus expression system. Protein Engineering 7, 537-541.

Holm, C., Davis, R. C., Østerlund, T., Schotz, M. C. \& Fredrikson, G. (1994). Identification of the active serine of hormone-sensitive lipase by site-directed mutagenesis. FEBS Letters 344, 234-238.

Holm, C., Fredrikson, G. \& Belfrage, P. (1986). Demonstration of the amphiphilic character of hormonesensitive lipase by temperature-induced phase separation in triton X-114 and charge-shift electrophoresis. Journal of Biological Chemistry 261, 15659-15661.

Holm, C., Kirchgessner, T. G., Svensson, K. L., Fredrikson, G., Nilsson, S., Miller, C. G., Shively, J. E., Heinzmann, C., Sparkes, R. S., Mohandas, T., Lusis, A. J., Belfrage, P. \& Schotz, M. C. (1988). Hormone-sensitive lipase: sequence, expression and chromosomal localization to 19 cent q13.3. Science 241 1503-1506.

Honnor, R. C., Dhillon, G. S. \& Londos, C. (1985). cAMP-dependent protein kinase and lipolysis in rat adipocytes. II. Definition of steady-state relationship with lipolytic and antilipolytic modulators. Journal of Biological Chemistry 260, 15130-15138

Hotamisligil, G. S., Arner, P., Caro, J. F., Atkinson, R. L. \& Spiegelman, B. M. (1995). Increased adipose tissue expression of tumor necrosis factor- $\alpha$ in human obesity and insulin resistance. Journal of Clinical Investigation 95, 2409-2415.

Jedlicka, A. E., Taylor, E. W., Meyers, D. A., Liu, Z. \& Levitt, R. C. (1994). Localization of the highly polymorphic locus D19S120 to 19p13.3 by linkage. Cytogenetics and Cell Genetics 65, 140.

Jepson, C. A. \& Yeaman, S. J. (1992). Inhibition of hormone-sensitive lipase by intermediary lipid metabolites. FEBS Letters 310, 197-200.

Kawakami, M., Murase, T., Igawa, H., Ishibashi, S., Mori, N., Takagu, F. \& Shibata, S. (1987). Human recombinant TNF suppresses lipoprotein lipase activity and stimulates lipolysis in 3T3-L1 cells. Journal of Biochemistry 101, 331-338. 
Kawamura, M., Jensen, D. F., Wancewicz, E. V., Joy, L. L., Khoo, J. C. \& Steinberg, D. (1981). Hormone-sensitive lipase in differentiated 3T3-L1 cells and its activation by cyclic AMP-dependent protein kinase. Proceedings of the National Academy of Sciences, USA 78, 732-736.

Kern, P. A., Saghizadeh, M., Ong, J. M., Bosch, R. J., Deem, R. \& Simsolo, R. B. (1995). The expression of tumor necrosis factor in human adipose tissue. Regulation by obesity, weight loss, and relationship to lipoprotein lipase. Journal of Clinical Investigation 95, 2111-2119.

Kraemer, F., Patel, S., Saedi, M. \& Sztalryd, C. (1993). Detection of hormone-sensitive lipase in various tissues. I. Expression of an HSL/bacterial fusion protein and generation of anti-HSL antibodies. Journal of Lipid Research 34, 663-671.

Kraemer, F. B., Tavanger, K. \& Hoffman, A. R. (1991). Developmental regulation of hormone-sensitive lipase mRNA in the rat: changes in steroidogenic tissues. Journal of Lipid Research 32, 1303-1310.

Lafontan, M. \& Berlan, M. (1993). Fat cell adrenergic receptors and the control of white and brown fat cell function. Journal of Lipid Research 34, 1057-1091.

Lafontan, M. \& Langin, D. (1995). Cellular aspects of fuel mobilization and selection in white adipocytes. Proceedings of the Nutrition Society 54, 49-63.

Langin, D. \& Holm, C. (1993). Sequence similarities between hormone-sensitive lipase and five prokaryotic enzymes. Trends in Biochemical Sciences 18, 466-467.

Langin, D., Laurell, H., Holst, L. S., Belfrage, P. \& Holm, C. (1993). Gene organization and primary structure of human hormone-sensitive lipase: possible significance of a sequence homology with a lipase of Moraxella TA144, an antarctic bacterium. Proceedings of the National Academy of Sciences, USA 90, 4897-4901.

Laurell, H., Grober, J., Holst, L. S., Holm, C., Mohrenwieser, H. \& Langin, D. (1995). The hormonesensitive lipase (LIPE) gene located on chromosome 19q13.1-13.2 is not duplicated on 19p13.3. International Journal of Obesity 19, 590-592.

Levitt, R. C., Jedlicka, A. E. \& Nouri, N. (1992). Dinucleotide repeat polymorphism at the hormone sensitive lipase (LIPE) locus. Human Molecular Genetics 1, 139.

Levitt, R. C., McKusick, V. A., Fletcher, J. E. \& Rosenberg, H. (1990). Gene candidate. Nature 345 , 297-298.

Levitt, R., Liu, Z., Nouri, N., Meyers, D., Brandriff, B. \& Mohrenwieser, H. (1995). Mapping of the gene for hormone-sensitive lipase (LIPE) to chromosome 19q13.1-13.2. Cytogenetics and Cell Genetics 69, 211-214.

Li, Z., Sumida, M., Birchbauer, A., Schotz, M. C. \& Reue, K. (1994). Isolation and characterization of the gene for mouse hormone-sensitive lipase. Genomics 24, 259-265.

Lönnqvist, F., Nyberg, B., Wahrenberg, H. \& Arner, P. (1990). Catecholamine-induced lipolysis in adipose tissue of the elderly. Journal of Clinical Investigation 85, 1614-1621.

Lopez-Aparicio, P., Belfrage, P., Manganiello, V. C., Kono, T. \& Degerman, E. (1993). Stimulation by insulin of the serine kinase in human platelets that phosphorylates and activates the cGMP-inhibited cAMP phosphodiesterase. Biochemical and Biophysical Research Communications 193, 1137-1144.

Manganiello, V. C., Degerman, E., Smith, C. J., Vasta, V., Tornqvist, H. \& Belfrage, P. (1992). Mechanisms for activation of the rat adipocyte particulate cyclic-GMP-inhibited cyclic AMP phosphodiesterase and its importance in the antilipolytic action of insulin. In Advances in Second Messenger and Phosphoprotein Research [S. J. Strada and H. Hidaka, editors]. New York: Raven Press Ltd.

Martin-Hidalgo, A., Holm, C., Belfrage, P., Schotz, M. C. \& Herrera, E. (1994). Lipoprotein lipase and hormone-sensitive lipase activity and $\mathrm{mRNA}$ in rat adipose tissue during pregnancy. American Journal of Physiology 266, E930-E935.

Mauriège, P., Galitzky, J., Berlan, M. \& Lafontan, M. (1987). Heterogeneous distribution of beta- and alpha-2-adrenoceptor binding sites in human fat cells from various fat deposits: functional consequences. European Journal of Clinical Investigation 17, 156-165.

Olsson, H. \& Belfrage, P. (1988). Phosphorylation and dephosphorylation of hormone-sensitive lipase. Interactions between the regulatory and basal phosphorylation sites. FEBS Letters 232, 78-82.

Patton, J., Shepard, H., Wilking, H., Lewis, G., Aggarwal, B., Eessalu, T., Gavin, L. \& Grunfeld, C. (1986). Interferons and tumor necrosis factors have similar catabolic effects on $3 \mathrm{~T} 3 \mathrm{L1}$ cells. Proceedings of the National Academy of Sciences, USA 83, 8313-8317.

Probst, M. R., Beer, M., Beer, D., Jenö, P., Meyer, U. A. \& Gasser, R. (1994). Human liver arylacetamide deacetylase. Molecular cloning of a novel esterase involved in the metabolic activation of arylamine carcinogens with high sequence similarity to hormone-sensitive lipase. Journal of Biological Chemistry 269, 21650-21656.

Reaven, G. (1988). Role of insulin resistance in human disease. Diabetes 37, 1595-1607. 
Reynisdottir, S., Ellerfeldt, K., Wahrenberg, H., Lithell, H. \& Arner, P. (1994). Multiple lipolysis defects in the insulin resistance (metabolic) syndrome. Journal of Clinical Investigation 93, 2590-2599.

Reynisdottir, S., Eriksson, M., Angelin, B. \& Arner, P. (1995a). Impaired activation of adipocyte lipolysis in familial combined hyperlipidemia. Journal of Clinical Investigation 95, 2161-2169.

Reynisdottir, S., Langin, D., Carlström, K., Holm, C., Rössner, S. \& Arner, P. (1995b). Effects of weight reduction on the regulation of lipolysis in adipocytes of women with upper-body obesity. Clinical Science 89, 421-429.

Ron, D., Brasier, A. R., McGehee, R. E. \& Habener, J. F. (1992). Tumor necrosis factor-induced reversal of adipocyte phenotype of 3T3-L1 cells is preceded by a loss of nuclear CCAAT/enhancer binding protein (C/EBP). Journal of Clinical Investigation 89, 223-233.

Schonk, D., Van Dijk, P., Riegmann, P., Trapman, J., Holm, C., Willcocks, T. C., Sillekens, P., Van Venrooij, W., Wimmer, E., Van Kessel, A. G., Ropers, H. H. \& Wieringa, B. (1990). Assignment of seven genes to distinct intervals on the midportion of human chromosome $19 \mathrm{q}$ surrounding the myotonic dystrophy gene region. Cytogenetics and Cell Genetics 54, 15-19.

Slavin, B. G., Ong, J. M. \& Kern, P. A. (1994). Hormonal regulation of hormone-sensitive lipase activity and mRNA levels in isolated rat adipocytes. Journal of Lipid Research 35, 1535-1541.

Smith, C. \& Manganiello, V. (1988). Role of hormone-sensitive low Km cAMP phosphodiesterase in regulation of cAMP-dependent protein kinase and lipolysis in rat adipocytes. Molecular Pharmacology 35 , $381-386$.

Smith, C. J., Vasta, V., Degerman, E., Belfrage, P. \& Manganiello, V. C. (1991). Hormone-sensitive cyclic GMP-inhibited cyclic AMP phosphodiesterase in rat adipocytes. Regulation of insulin- and cAMPdependent activation by phosphorylation. Journal of Biological Chemistry 266, 13385-13390.

Spiegelman, B. M. \& Hotamisligil, G. S. (1993). Through thick and thin: wasting, obesity, and TNF $\alpha$. Cell 73, 625-627.

Strălfors, P. \& Belfrage, P. (1983). Phosphorylation of hormone-sensitive lipase by cyclic AMP-dependent protein kinase. Journal of Biological Chemistry 258, 15146-15152.

Strålfors, P., Olsson, H. \& Belfrage, P. (1987). Hormone-sensitive lipase. In The Enzymes, pp. 147-177 [P. D. Boyer and E. G. Krebs, editors]. New York: Academic Press.

Sullivan, J. E., Brocklehurst, K. J., Marley, A. E., Carey, F., Carling, D. \& Beri, R. K. (1994). Inhibition of lipolysis and lipogenesis in isolated rat adipocytes with AICAR, a cell-permeable activator of AMPactivated protein kinase. FEBS Letters 353, 33-36.

Sumida, M., Sekiya, K., Okuda, H., Tanaka, Y. \& Shiosaka, T. (1990). Inhibitory effect of tumor necrosis factor on gene expression of hormone sensitive lipase in 3T3-L1 adipocytes. Journal of Biochemistry 107, $1-2$.

Sztalryd, C., Komaromy, M. \& Kraemer, F. (1995). Overexpression of hormone-sensitive lipase prevents triglyceride accumulation in adipocytes. Journal of Clinical Investigation 95, 2652-2661.

Sztalryd, C. \& Kraemer, F. B. (1994). Differences in hormone-sensitive lipase expression in white adipose tissue from various anatomic locations of the rat. Metabolism 43, 241-247.

Sztalryd, C. \& Kraemer, F. B. (1994). Regulation of hormone-sensitive lipase during fasting. American Journal of Physiology 266, E179-E185.

Tavernier, G., Galitzky, J., Valet, P., Remaury, A., Bouloumié, A., Lafontan, M. \& Langin, D. (1995). Molecular mechanisms underlying regional variations of catecholamine-induced lipolysis in rat adipocytes. American Journal of Physiology 268, E1135-E1142.

Thompson, M. P., Cooper, S. T., Parry, B. R. \& Tuckey, J. A. (1993). Increased expression of the mRNA for hormone-sensitive lipase in adipose tissue of cancer patients. Biochimica et Biophysica Acta 1180, $236-242$.

Wang, S., Lapierre, P., Robert, M.-F., Nadeau, J. H. \& Mitchell, G. A. (1994). Hormone-sensitive lipase maps to proximal chromosome 7 in mice and is genetically distinct from the Ad and Tub loci. Genomics 24, $416-417$.

Warden, C. H., Davis, R. C., Yoon, M. Y., Hui, D. Y., Svenson, K., Xia, Y. R., Diep, A., He, K. Y. \& Lusis, A. J. (1993). Chromosomal localization of lipolytic enzymes in the mouse: pancreatic lipase, colipase, hormone-sensitive lipase, hepatic lipase, and carboxyl ester lipase. Journal of Lipid Research 34, 1451-1455.

Warden, C. H., Fisler, J. S., Shoemaker, S. M., Wen, P.-Z., Svenson, K. L., Pace, M. J. \& Lusis, A. J. (1995). Identification of four chromosomal loci determining obesity in a multifactorial mouse model. Journal of Clinical Investigation 95, 1545-1552.

Wesslau, C., Eriksson, J. \& Smith, U. (1993). Cellular cyclic AMP levels modulate insulin sensitivity and responsiveness. Evidence against a significant role of $\mathrm{Gi}$ in insulin signal transduction. Biochemical and Biophysical Research Communications 196, 287-293. 
Wilson, B. E., Deeb, S. \& Florant, G. L. (1992). Seasonal changes in hormone-sensitive and lipoprotein lipase mRNA concentrations in marmot white adipose tissue. American Journal of Physiology 262, R177-R181.

Wise, L. \& Jungas, R. (1978). Evidence for a dual mechanism of lipolysis activation by epinephrine in rat adipose tissue. Journal of Biological Chemistry 253, 2624-2627.

Wood, S. L., Emmison, N., Borthwick, A. C. \& Yeaman, S. J. (1993). The protein phosphatases responsible for dephosphorylation of hormone-sensitive lipase in isolated rat adipocytes. Biochemical Journal 295, $531-535$. 